\title{
Subchronic and Genetic Safety Assessment of a New Medicinal Dendrobium Species: Dendrobium Taiseed Tosnobile in Rats
}

\author{
Li-Chan Yang, ${ }^{1}$ Jiunn-Wang Liao, ${ }^{2}$ Chi-Luan Wen, ${ }^{3}$ and Wen-Chuan Lin ${ }^{1}{ }^{1}$ \\ ${ }^{1}$ Department of Pharmacy, School of Pharmacy, China Medical University, Taichung, Taiwan \\ ${ }^{2}$ Graduate Institute of Veterinary Pathobiology, National Chung Hsing University, Taichung, Taiwan \\ ${ }^{3}$ Taiwan Seed Improvement and Propagation Station, Council of Agriculture, Taichung, Taiwan \\ Correspondence should be addressed to Wen-Chuan Lin; wclin@mail.cmu.edu.tw
}

Received 15 November 2017; Accepted 9 January 2018; Published 6 February 2018

Academic Editor: Yew-Min Tzeng

Copyright (C) 2018 Li-Chan Yang et al. This is an open access article distributed under the Creative Commons Attribution License, which permits unrestricted use, distribution, and reproduction in any medium, provided the original work is properly cited.

\begin{abstract}
Dendrobium Taiseed Tosnobile is a new species of herba dendrobii (Shi-Hu) that was developed by crossbreeding D. tosaense and D. nobile. Its pharmacological activity and active component have been reported, but its subchronic toxicity and genetic safety have not yet been investigated. This study assessed the 90-day oral toxicity and genetic safety of the aqueous extracts of $D$. Taiseed Tosnobile (DTTE) in male and female Sprague-Dawley (SD) rats. Eighty rats were divided into four groups, each consisting of ten male and ten female rats. DTTE was given orally to rats at 800,1600 , or $2400 \mathrm{mg} / \mathrm{kg}$ for 90 consecutive days, and distilled water was used for the control group. Genotoxicity studies were performed using a bacterial reverse mutation assay and in vivo mammalian cell micronucleus test in ICR mice and analyzed using flow cytometry. Throughout the study period, no abnormal changes were observed in clinical signs and body weight or on ophthalmological examinations. Additionally, no significant differences were found in urinalysis, hematology, and serum biochemistry parameters between the treatment and control groups. Necropsy and histopathological examination indicated no treatment-related changes. Based on results, the no-observed-adverse-effect level of DTTE is greater than $2400 \mathrm{mg} / \mathrm{kg}$ in SD rats.
\end{abstract}

\section{Introduction}

The raw pharmacognosy of herba dendrobii (Shi-Hu), a medicinal orchid (family: Orchidaceae), is well known; it has been widely used for health improvement as an herbal tea, and it is also included in traditional Chinese and other Asian folk medicines for its antipyretic, ophthalmic, and tonic benefits $[1,2]$. Unlike other medicinal material herbs that usually comprise only one species, herba dendrobii is prepared from several Dendrobium species-namely, $D$. tosaense, D. huoshanense, D. nobile, and D. candidum $[1,3,4]$. Herba dendrobii is highly valuable, but its growth rate is slow and its distribution in the wild is sparse; therefore, it is a protected herb before. Recently, researchers have attempted to improve the large-scale cultivation of herba dendrobii. One solution was to develop a new giant-type species with a higher growth rate. $D$. Taiseed Tosnobile is a new species developed by crossbreeding $D$. tosaense and $D$. nobile as the seed parent and the pollen parent, respectively, by the Taiwan
Seed Improvement and Propagation Station [4]. It exhibits the characteristics of high yield and easy cultivation and has no special pest control requirements.

Numerous studies have reported the structural characteristics and some pharmacological properties of the polysaccharides of other Dendrobium species, which include antitumor, antihyperglycemic, antioxidant, hepatoprotective, epithelial repairing, and immunomodulatory activities [4-9]. Among the pharmacological activities of the polysaccharides of dendrobium, immunomodulatory activity is the most common activity. As a new species of herba dendrobii, demonstrating the functional components, pharmacologic properties, and safety is necessary. Yang et al. (2017) reported that polysaccharides from aqueous extracts of $D$. Taiseed Tosnobile have immunostimulating action in vivo. Additionally, no safety studies on $D$. Taiseed Tosnobile have been conducted. In tradition, the way that people use herba dendrobii is by extracting the stem with boiling water. Therefore, this study demonstrated the safety of aqueous extracts of D. 
TABLE 1: Composition analysis of DTTE.

\begin{tabular}{lc}
\hline Items & Content $($ per $100 \mathrm{~g})$ \\
\hline Calories & $425.7 \mathrm{kcal}$ \\
Crude protein & $3.2 \mathrm{~g}$ \\
Crude fat & $18.1 \mathrm{~g}$ \\
Saturated fatty acids & $2.0 \mathrm{~g}$ \\
Trans fatty acids & Trace \\
Carbohydrate & $62.5 \mathrm{~g}$ \\
Sodium & $21 \mathrm{mg}$ \\
Moisture & $26 \%$ \\
\hline
\end{tabular}

Taiseed Tosnobile, but not other components from $D$. Taiseed Tosnobile to meet the general mode of use. Therefore, to better understand the availability of this new Dendrobium species, we performed a 90-day subchronic toxicity study of the oral administration of the aqueous extract of $D$. Taiseed Tosnobile (DTTE) and conducted a genetic safety assessment using the bacterial reverse mutation assay and micronucleus test in vivo.

\section{Materials and Methods}

2.1. Material Preparation. The plant material of $D$. Taiseed Tosnobile was provided by the Taiwan Seed Improvement and Propagation Station (Taichung, Taiwan). The dry stems were extracted by $95^{\circ} \mathrm{C}$ distilled water over $1 \mathrm{~h}$, and then the aqueous extracts were evaporated under reduced pressure to decrease the volume. DTTE was stored at $-20^{\circ} \mathrm{C}$ until used and the yield rate was $20.3 \%$ in dry stems. The yields of crude polysaccharides were $8.3 \%$ for dry stems. The moisture of DTTE was $26.3 \%$. The composition analysis of DTTE is shown in Table 1. DTTE includes calories, crude protein, crude fat, saturated fatty acids, trans fatty acids, and carbohydrate according to the Association of Official Agricultural Chemists (AOAC) official procedures [10].

\subsection{0-Day Oral Exposure Study}

2.2.1. Animals and Treatment. This 90 -day subchronic toxicity study was designed to evaluate oral exposure of DTTE according to the Organization for Economic Cooperation and Development (OECD) guideline 408. Animal experimental protocols complied with the institutional guidelines of China Medical University for the use of laboratory animals. The guidelines corresponded to the National Institutes of Health guide for the care and use of laboratory animals (NIH Publications number 8023, revised 1978). Six-week-old Sprague-Dawley (SD) rats were purchased from BioLASCO Taiwan Co., Ltd. (Yilan, Taiwan), and were acclimated for 2 weeks before beginning the experiment. The initial body weight of the rats was $247 \pm 7 \mathrm{~g}$ and $187 \pm 7 \mathrm{~g}$ for the males and females, respectively. The rats were housed in an air-conditioned room $\left(21-24^{\circ} \mathrm{C}\right)$ with humane care and $12 \mathrm{~h}$ of light daily (8:00 a.m. to 8:00 p.m.); they were also allowed free access to food pellets and water throughout the study period. The rats were randomly divided into the control and treatment groups of ten rats per sex per group. DTTE was given to the experimental rats daily by gavage at different doses-800, 1600, or $2400 \mathrm{mg} / \mathrm{kg}$-and distilled water was given to the control group. To prevent adverse effects from gavage, the volume of DTTE in different dosage and water was calculated to be $10 \mathrm{~mL} / \mathrm{kg}$. During the experimental period, all animals were observed twice daily for mortality, morbidity, and clinical signs of toxicity. Body weight was measured pretest, weekly, and on the day of sacrifice after overnight fasting. Moreover, food consumption was determined weekly. At the end of the experiment, all surviving animals were anesthetized with isoflurane (Piramal Critical Care, PA, USA) and euthanized after blood collection.

2.2.2. Urinalysis. During the last week of the study, each surviving rat was placed in a metabolic cage for $16 \mathrm{~h}$ to collect urine. The appearance, color, and volume of the urine samples were determined, and they were also analyzed for $\mathrm{pH}$, specific gravity, leukocytes, occult blood, nitrite, protein, glucose, ketones, urobilinogen, and bilirubin with an autoanalyzer (Urisys 1100, Roche, Switzerland). Sediments of each urine sample were microscopically examined for leukocytes, red blood cells (RBCs), epithelial cells, microbes, crystals, and casts.

2.2.3. Hematology and Serum Biochemistry. After overnight fasting, all surviving rats received anesthesia and were subject to bloodletting for euthanization. The blood was examined for blood sugar immediately using a commercial glucose meter with strips (Accu-Chek, Roche, Germany). The blood was collected in a spray-dried $\mathrm{K}_{3}$ EDTA blood collection tube (Greiner Bio-One, Austria) and mixed well. A complete blood count (CBC) counter was applied to the following detection: erythrocytes, hemoglobin, hematocrit, mean corpuscular volume (MCV), mean corpuscular hemoglobin $(\mathrm{MCH})$, mean corpuscular hemoglobin concentration (MCHC), platelets, and leucocytes. Then, a blood smear was prepared and stained using the commercial DiffQuick Stain kit (Sysmex Corporation, Japan) for the microscopic detection of lymphocytes and neutrophils. If effects on the hematopoietic system were noted, reticulocyte count and terminal bone marrow cytology were examined microscopically. Further, $1.8 \mathrm{~mL}$ of blood sample was placed in a coagulation tube containing 3.2\% sodium citrate (Becton Dickinson, USA) and then centrifuged at $1500 \mathrm{~g}$ for $15 \mathrm{~min}$ to separate the serum, which was analyzed for the prothrombin time (PT) and the activated partial thromboplastin time (APTT). Other blood samples were collected in blood collection tubes containing $Z$ serum clot activator (Greiner Bio-One), after which the serum was separated. The following clinical chemistry parameters were analyzed using an automatic biochemical analyzer (Cobas Mira Plus, Roche, Germany): total protein (TP), albumin (ALB), aspartate aminotransferase (AST), alanine aminotransferase (ALT), alkaline phosphatase (ALP), total bilirubin (TBIL), gamma-glutamyl transferase (GGT), creatinine (CREA), blood urea nitrogen (BUN), and 
electrolytes, including sodium, potassium, chloride, calcium, and phosphate.

2.2.4. Pathology. At the end of the treatment, all surviving animals were fasted overnight and sacrificed the following day by exsanguination and euthanization. Before sacrifice, the rats were weighed and external and internal gross pathological examinations were performed. The weights of major organs such as the brain, heart, kidney, liver, spleen, adrenal gland, testes, and ovaries were recorded after the removal of peripheral fat tissue. In addition, relative organ weights were calculated against the fasting body weight. The peripheral oral cavity, cranial cavity, and all tissues and organs in the thoracic and abdominal cavities were examined visually for any abnormality. Histopathological examinations were performed on the brain, heart, kidney, liver, spleen, adrenals, testes, ovaries, aorta, bone marrow, duodenum, jejunum, ileum, caecum, colon, rectum, eyes, esophagus, mammary gland, Harderian gland, trachea, lung, lymph node, pancreas, sciatic nerve, pituitary, prostate gland, salivary gland, skin, spinal cord, stomach, thigh muscle, thymus, thyroid/parathyroid gland, urinary bladder, and uterus. Except for the testes and eyes, all of the aforementioned collected tissues were fixed in $10 \%$ neutral buffered formalin (Tonyar Biotech, Taiwan). The lungs were inflated with a fixative prior to immersion in the formalin. The eyes and testes were fixed in modified Davidson's Fluid for 48 hours and then briefly washed in tap water before being transferred to the $10 \%$ neutral buffered formalin for storage prior to trimming and processing [11]. Preserved organs and tissues were dehydrated, clarified, infiltrated with paraffin, and embedded after trimming to form paraffin tissue blocks, which were sliced into $5 \mu \mathrm{m}$ thick sections using a microtome (Leica RM 2145, Germany); these sections were stained with hematoxylin and eosin (HE). Histopathological analysis was conducted using an optical microscope (Optiphot-2; Nikon, Japan). All tissues from animals in the control and highdose groups were examined, with gross lesions examined microscopically. If treatment-related effects were noted in certain tissues, we evaluated the tissue samples of the rats at the next lower dose. Successive examination of the next lower doses continued until no effects were noted. We also performed microscopic examinations of all tissues from all the animals (both those that died prematurely and those sacrificed at the end of the study) to assess any potential toxic effects.

\subsection{Genotoxicity Studies}

2.3.1. Bacterial Reverse Mutation Assay (Ames Test). Bacterial mutation assay was performed according to Health Effects Test Guidelines, Bacterial Reverse Mutation Test [12], and OECD Guidelines for the Testing of Chemicals, Section 4: Health Effects, number 473: Bacterial Reverse Mutation Test [13]. Strains TA98 and TA100 of the histidine-requiring Salmonella typhimurium were purchased from the Bioresources Collection and Research Center (FIRDI, Hsinchu, Taiwan) and strains TA102, TA1535, and TA1537 were purchased from Discovery Partners International (DPI, USA). The genotypes of the bacterial strains were confirmed by histidine mutation, rfa mutation, uvrB repair, and ampicillin resistance before the assay; also prior to the assay, a dose range-finding test was performed with DTTE $(1.25,2.5$, and $5 \mathrm{mg} /$ plate $)$ in the tester strains. A plate incorporation assay was employed and performed to detect a reverse mutation in bacterial strains. Briefly, $0.1 \mathrm{~mL}$ of aqueous solution of DTTE $(0.313,0.625$, $1.25,2.5$, and $5 \mathrm{mg} /$ plate) was mixed with $0.1 \mathrm{~mL}$ of overnight culture of the $S$. typhimurium strains $\left(2 \times 10^{9}\right.$ cells $\left./ \mathrm{mL}\right)$ in $0.5 \mathrm{~mL}$ of $0.2 \mathrm{M}$ phosphate buffer either without or with the $\mathrm{S} 9$ metabolic activation mix $(0.5 \mathrm{~mL})$. The composition of the S9 mixture was 5\% $v / v$ Aroclor-1254 that had been induced in rat livers (Lot\#2901, MoltoxTM, USA) and $0.15 \mathrm{M} \mathrm{KCl}$ (Sigma-Aldrich, USA). The S9 mixture was subsequently mixed with $2 \mathrm{~mL}$ of molten top agar solution with $0.5 \mathrm{mM}$ histidine/biotin. Next, the cultures were incubated at $50^{\circ} \mathrm{C} \pm$ $1^{\circ} \mathrm{C}$ before being transferred to minimal-glucose agar plates. The solidified agar plates were inverted and incubated at $37^{\circ} \mathrm{C} \pm 1^{\circ} \mathrm{C}$ for $48-72 \mathrm{~h}$; then, the colonies were counted. Double distilled water served as the negative control. Positive reagents without S-9 mix reactions were $2.5 \mu \mathrm{g} /$ plate 4 nitroquinoline- $\mathrm{N}$-oxide for TA98, $5 \mu \mathrm{g} /$ plate sodium azide for TA100, TA1535, and $0.5 \mu \mathrm{g} /$ plate mitomycin C for TA102, and $50 \mu \mathrm{g} /$ plate 9 -aminoacridine for TA1537; positive reagent with S-9 mix reactions was $5 \mu \mathrm{g} /$ plate 2 -aminoanthracene for all Salmonella strains.

2.3.2. In Vivo Mammalian Cell Micronucleus Test. The micronucleus test was performed as described by Bemis et al. (2008) using a commercial MicroFlowPLUS Kit (Becton Dickinson). Twelve-week-old male ICR mice (body weight, 25-30 g) were purchased from BioLASCO Taiwan Co., Ltd. All positive control group mice were given $100 \mathrm{mg} / \mathrm{kg}$ cyclophosphamide via intraperitoneal injection $(10 \mathrm{~mL} / \mathrm{kg})$; then, the test sample groups received DTTE orally at 800 , 1600 , or $2400 \mathrm{mg} / \mathrm{kg}$ (dosed at $10 \mathrm{~mL} / \mathrm{kg}$ ). The negative control group received sterile water at $10 \mathrm{~mL} / \mathrm{kg}$. All doses were administered using a stainless steel feeding needle. The mice were monitored daily for any posttreatment clinical symptoms, and their body weight before and after treatment was noted. At 24 and $48 \mathrm{~h}$ posttreatment, $60 \mu \mathrm{L}$ of blood was collected in a $\mathrm{K}_{3}$ EDTA tube (BD) by tail vein bleeding. Blood samples were then fixed with ultra-cold methanol and were kept for at least $48 \mathrm{~h}$ at $-80^{\circ} \mathrm{C}$ for use in flow cytometric analysis. Fixed blood cells were washed and centrifuged, and the washed cells were stained with a labeled solution containing RNase, anti-CD71-FITC (BioLegend), and anti-CD61 PE for $30 \mathrm{~min}$ at $4^{\circ} \mathrm{C}$. Next, the samples were moved to room temperature and incubated for $30 \mathrm{~min}$ at room temperature to ensure the complete degradation of cellular RNA. Then, all samples were kept on ice until analysis. Samples were suspended by gently tapping the tube, adding $1 \mathrm{~mL}$ of DNA staining solution (propidium iodide, PI), and placing the tube on the cytometer. The $\mathrm{CD}^{-} 1^{-}$mouse blood sample, $\mathrm{PI}^{-}$blood sample, and $\mathrm{CD}^{-} 1^{-}$blood sample were used for compensation before flow cytometry analysis (Becton Dickinson FASCScan, Mountain View, USA). Reticulocytes (RETs) are $\mathrm{CD}^{+}{ }^{+}$cells, and at least 20,000 CD71 ${ }^{+}$RETs were collected for each sample; \% RET $=\mathrm{CD} 1^{+}$cells/total cells. MN-RETs are 


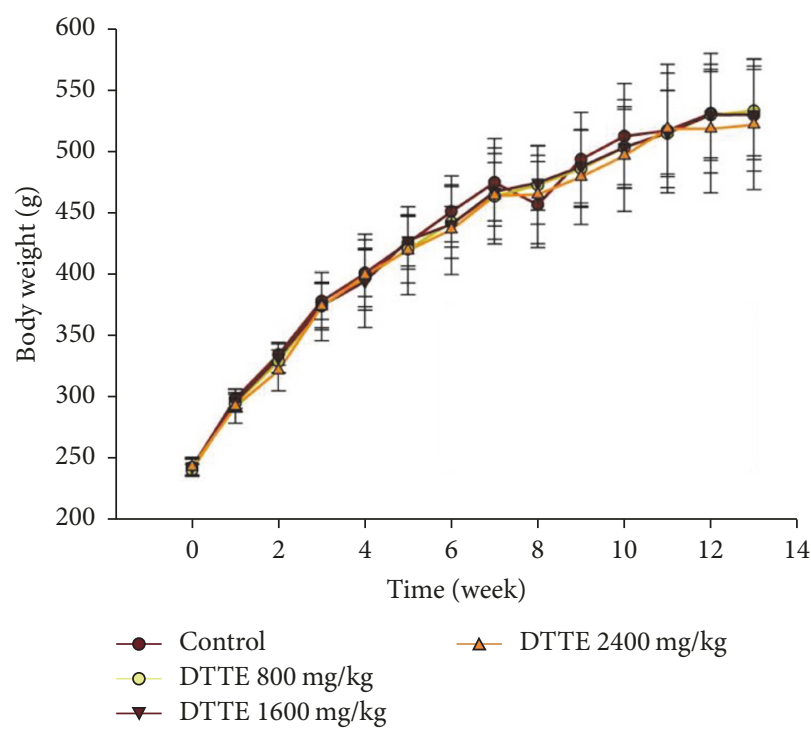

(a)

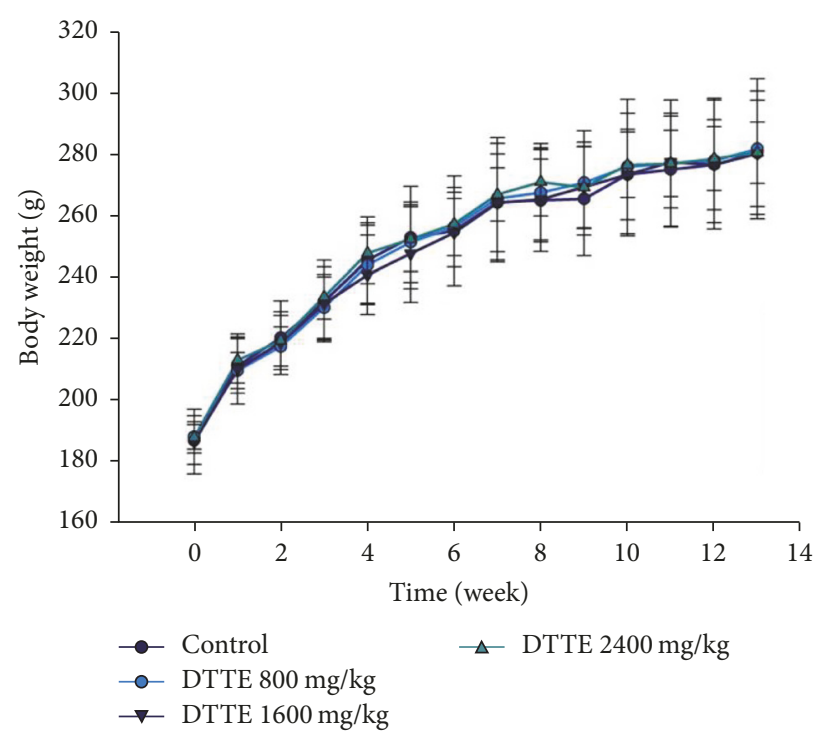

(b)

FIGURE 1: The body weight change of SD rats during the administration of DTTE for 90 days. (a) Male rats and (b) female rats. Data are expressed as the mean $\pm \mathrm{SD}(n=10)$.

$\mathrm{CD}^{-}$and PI-positive cells and were calculated as follows: $\left(\mathrm{CD}_{1} 1^{+}+\mathrm{PI}^{+}\right) / \mathrm{CD} 1^{+}$. Normal RBC cells were depicted as $\mathrm{CD}^{-} 1^{-} / \mathrm{PI}^{-}$.

2.4. Statistical Analysis. All data were expressed as mean \pm standard deviation. The analyses of body weight, feed consumption, organ weight, hematology, and serum biochemistry were performed with one-way analysis of variance using PASW Statistics software (IBM, USA). Duncan's test was used to determine the statistical significance $(P<0.05)$ between the control and treatment groups, and male and female rats were evaluated separately.

\section{Results}

\subsection{0-Day Oral Exposure Study}

3.1.1. Clinical Observation, Feed Consumption, and Body Weight. No rats died, and no clinical signs of toxicity or mortality related to DTTE administration at any dose were observed in the rats during this 90-day subchronic study. Food consumption between the DTTE-treated groups and the control group was the same (Figure 1). Compared with the control group, no significant influences were observed in the DTTE-treated male and female groups (Figure 1). Ophthalmoscopic examinations revealed no abnormality in the DTTE-treated or control groups.

3.1.2. Urinalysis. No significant differences in urine sediments or urinalysis response variables were observed between the treatment and control groups of both sexes (data not shown).

3.1.3. Hematology and Serum Biochemistry. The platelet count in male rats who received $2400 \mathrm{mg} / \mathrm{kg}$ DTTE was significantly lower than that in the control group (Table 2); however, the platelet count was still within the normal range, which is verified by a previous report.

After 90 days, the lymphocyte count and segmented neutrophil count in female rats given DTTE $800 \mathrm{mg} / \mathrm{kg}$ were lower and higher than those in the control group, respectively. However, the lymphocyte count was not significantly different between the control and low-dose groups (5.8 \pm 0.5 and $6.1 \pm 0.8 \times 10^{3} / \mu \mathrm{L}$, resp.). The segmented neutrophil count in the low-dose DTTE-treated females $\left(0.59 \pm 0.11 \times 10^{3} / \mu \mathrm{L}\right)$ did not significantly increase compared to that in the control group $\left(0.74 \pm 0.08 \times 10^{3} / \mu \mathrm{L}\right)$. Results showed that the statistical differences observed in one sex were not observed in the other and were found to be non-dose-dependent. No other hematological parameters in either sex were significantly different compared to those in the controls.

Table 3 shows the results of the serum biochemistry analysis. Serum sodium among the high-dose group was significantly higher than that of the control group in male rats, whereas serum chloride among the high-dose group was significantly higher than that of the control group in female rats. Notably, both serum electrolytes were still within the normal range, according to a previous report [14]. Other small yet significant changes following DTTE administration were observed in the serum biochemistry parameters and were considered to be incidental changes (i.e., biological variations) and not treatment-related adverse effects.

3.1.4. Pathology. No treatment-related gross pathological changes were observed in any group. Moreover, no treatmentrelated changes were observed in tissues of the peripheral cavity, thymus, heart, lung, liver, kidney, gastrointestinal tract, spleen, brain, and the reproductive system in the 
TABLE 2: Hematology parameters of SD male and female rats fed with 800, 1600, and $2400 \mathrm{mg} / \mathrm{kg}$ DTTE for 90 days.

\begin{tabular}{|c|c|c|c|c|}
\hline Parameters & Control & $800 \mathrm{mg} / \mathrm{kg}$ & $1600 \mathrm{mg} / \mathrm{kg}$ & $2400 \mathrm{mg} / \mathrm{kg}$ \\
\hline \multicolumn{5}{|c|}{ Erythrocytes $\left(10^{6} / \mu \mathrm{L}\right)$} \\
\hline M & $8.2 \pm 0.5$ & $8.3 \pm 0.5$ & $8.3 \pm 0.3$ & $8.3 \pm 0.4$ \\
\hline $\mathrm{F}$ & $7.2 \pm 0.1$ & $7.4 \pm 0.1$ & $7.4 \pm 0.1$ & $7.4 \pm 0.1$ \\
\hline \multicolumn{5}{|c|}{ Hemoglobin (g/dL) } \\
\hline M & $15.2 \pm 0.6$ & $15.5 \pm 0.5$ & $5.7 \pm 0.5$ & $15.2 \pm 0.6$ \\
\hline $\mathrm{F}$ & $14.6 \pm 0.1$ & $15.1 \pm 0.3$ & $15.0 \pm 0.2$ & $14.7 \pm 0.2$ \\
\hline \multicolumn{5}{|c|}{ Hematocrit (\%) } \\
\hline $\mathrm{M}$ & $45.5 \pm 2.5$ & $46.5 \pm 2.2$ & $46.9 \pm 1.4$ & $46.3 \pm 2.1$ \\
\hline $\mathrm{F}$ & $42.1 \pm 0.6$ & $43.5 \pm 0.7$ & $43.3 \pm 0.4$ & $43.1 \pm 0.6$ \\
\hline \multicolumn{5}{|l|}{$\operatorname{MCV}\left(\mu^{3}\right)$} \\
\hline M & $55.5 \pm 1.1$ & $56.2 \pm 1.9$ & $56.0 \pm 1.6$ & $56.1 \pm 1.5$ \\
\hline $\mathrm{F}$ & $58.4 \pm 0.3$ & $58.6 \pm 0.5$ & $58.5 \pm 0.5$ & $58.7 \pm 0.6$ \\
\hline \multicolumn{5}{|l|}{$\mathrm{MCH}(\mathrm{pg})$} \\
\hline M & $18.6 \pm 0.6$ & $18.7 \pm 1.0$ & $18.8 \pm 0.8$ & $18.4 \pm 0.5$ \\
\hline $\mathrm{F}$ & $20.2 \pm 0.2$ & $20.4 \pm 0.2$ & $20.3 \pm 0.2$ & $20.0 \pm 0.3$ \\
\hline \multicolumn{5}{|c|}{ MCHC (g/dL) } \\
\hline M & $33.5 \pm 0.6$ & $33.2 \pm 0.8$ & $33.4 \pm 0.7$ & $32.9 \pm 0.3$ \\
\hline $\mathrm{F}$ & $34.5 \pm 0.2$ & $34.7 \pm 0.2$ & $34.7 \pm 0.2$ & $34.0 \pm 0.2$ \\
\hline \multicolumn{5}{|c|}{ Platelets $\left(10^{3} / \mu \mathrm{L}\right)$} \\
\hline $\mathrm{M}$ & $1185 \pm 108$ & $1107 \pm 159$ & $1109 \pm 125$ & $996 \pm 238^{*}$ \\
\hline $\mathrm{F}$ & $1108 \pm 49$ & $1074 \pm 52$ & $1160 \pm 45$ & $1132 \pm 42$ \\
\hline \multicolumn{5}{|c|}{ Leukocytes $\left(10^{3} / \mu \mathrm{L}\right)$} \\
\hline $\mathrm{M}$ & $10.7 \pm 2.6$ & $8.4 \pm 2.2$ & $10.4 \pm 4.6$ & $9.0 \pm 1.5$ \\
\hline $\mathrm{F}$ & $6.3 \pm 0.5$ & $6.9 \pm 0.9$ & $7.1 \pm 0.4$ & $6.2 \pm 0.6$ \\
\hline \multicolumn{5}{|c|}{ Lymphocytes (\%) } \\
\hline M & $88.5 \pm 2.9$ & $89.2 \pm 2.6$ & $83.8 \pm 18.3$ & $87.1 \pm 4.4$ \\
\hline $\mathrm{F}$ & $91.9 \pm 0.9$ & $88.9 \pm 0.8^{*}$ & $90.6 \pm 0.5$ & $90.7 \pm 0.6$ \\
\hline \multicolumn{5}{|c|}{ Seg. Neu (\%) } \\
\hline $\mathrm{M}$ & $11.5 \pm 2.9$ & $10.8 \pm 2.6$ & $16.2 \pm 18.3$ & $13.0 \pm 4.4$ \\
\hline $\mathrm{F}$ & $8.1 \pm 0.9$ & $11.2 \pm 0.8^{*}$ & $9.4 \pm 0.5$ & $9.3 \pm 0.6$ \\
\hline \multicolumn{5}{|l|}{ PT (sec) } \\
\hline M & $10.0 \pm 0.2$ & $10.4 \pm 1.2$ & $10.1 \pm 0.4$ & $10.0 \pm 0.2$ \\
\hline $\mathrm{F}$ & $10.8 \pm 0.5$ & $11.0 \pm 0.4$ & $11.0 \pm 0.8$ & $11.5 \pm 1.4$ \\
\hline \multicolumn{5}{|l|}{ APTT (sec) } \\
\hline M & $17.4 \pm 0.8$ & $18.6 \pm 2.6$ & $18.8 \pm 1.8$ & $17.7 \pm 0.7$ \\
\hline $\mathrm{F}$ & $23.7 \pm 2.3$ & $21.0 \pm 1.9^{*}$ & $22.1 \pm 2.6$ & $24.2 \pm 2.8$ \\
\hline
\end{tabular}

All values are means $\pm \mathrm{SD} .{ }^{*} P<0.05$ as compared with the control group; M: male; F: female; and Seg. Neu: segmented neutrophil.

treatment or control groups (Table 4), and no significant intersex difference was observed for absolute organ weight compared with the control group. Additionally, no significant differences were found in the relative organ weight between either sex or the control group (data not shown).

The histopathological examination was performed on 40 rats (ten rats per sex from the control and high-dose group), and the results are shown in Table 5. No significant treatmentrelated changes were observed in either the DTTE-treated or control groups among the males and females. In males, slight mononuclear cell infiltration (focal) was found in the heart, with the incidence rate of this phenomenon in the control and high-dose group 2/10 and 1/10, respectively. Slight to moderate focal hydronephrosis and focal mononuclear cell infiltration were found in the kidney of the male control group, and the incidence rate of these phenomena was $2 / 10$ and $1 / 10$, respectively. Notably, only one male rat in the control group present focal slight tubular regeneration in the kidneys. Both control and high-dose groups had focal, slight, mononuclear cell infiltration in the prostate gland, and the incidence rate of this phenomenon was $2 / 10$ for both groups. Only one female rat in the high-dose DTTE-treated group presented with a focal and moderate epidermoid cyst 
TABLE 3: Clinical biochemistry of SD male and female rats fed with 800, 1600, and $2400 \mathrm{mg} / \mathrm{kg}$ DTTE for 90 days.

\begin{tabular}{|c|c|c|c|c|}
\hline Parameters & Control & $800 \mathrm{mg} / \mathrm{kg}$ & $1600 \mathrm{mg} / \mathrm{kg}$ & $2400 \mathrm{mg} / \mathrm{kg}$ \\
\hline \multicolumn{5}{|l|}{$\operatorname{ALP}(\mathrm{U} / \mathrm{L})$} \\
\hline $\mathrm{M}$ & $50.7 \pm 7.7$ & $50.7 \pm 11.9$ & $53.1 \pm 7.5$ & $54.1 \pm 9.1$ \\
\hline $\mathrm{F}$ & $29.2 \pm 5.7$ & $25.7 \pm 3.6$ & $28.3 \pm 5.4$ & $31.0 \pm 10.0$ \\
\hline \multicolumn{5}{|l|}{ AST (U/L) } \\
\hline M & $59.1 \pm 7.8$ & $58.5 \pm 6.9$ & $54.5 \pm 8.3$ & $66.6 \pm 7.3$ \\
\hline $\mathrm{F}$ & $62.0 \pm 9.9$ & $84.7 \pm 17.0$ & $81.2 \pm 13.3$ & $63.1 \pm 9.7$ \\
\hline \multicolumn{5}{|l|}{$\operatorname{ALT}(\mathrm{U} / \mathrm{L})$} \\
\hline M & $37.3 \pm 5.8$ & $38.7 \pm 5.1$ & $35.3 \pm 3.3$ & $43.2 \pm 16.2$ \\
\hline $\mathrm{F}$ & $34.0 \pm 8.2$ & $28.2 \pm 3.3$ & $32.2 \pm 4.3$ & $40.3 \pm 5.6$ \\
\hline \multicolumn{5}{|l|}{$\gamma$-GT (IU/L) } \\
\hline $\mathrm{M}$ & $2.7 \pm 1.6$ & $2.9 \pm 2.4$ & $2.6 \pm 2.1$ & $1.6 \pm 1.4$ \\
\hline $\mathrm{F}$ & $2.3 \pm 1.3$ & $2.9 \pm 2.6$ & $2.1 \pm 1.3$ & $2.1 \pm 1.0$ \\
\hline \multicolumn{5}{|c|}{ T-protein (g/dL) } \\
\hline $\mathrm{M}$ & $6.1 \pm 0.2$ & $6.1 \pm 0.2$ & $6.1 \pm 0.2$ & $6.1 \pm 0.3$ \\
\hline $\mathrm{F}$ & $6.4 \pm 0.2$ & $6.5 \pm 0.2$ & $6.4 \pm 0.2$ & $6.6 \pm 0.5$ \\
\hline \multicolumn{5}{|c|}{ Albumin (g/dL) } \\
\hline $\mathrm{M}$ & $3.1 \pm 0.2$ & $3.2 \pm 0.1$ & $3.0 \pm 0.1$ & $3.2 \pm 0.1$ \\
\hline $\mathrm{F}$ & $3.6 \pm 0.1$ & $3.8 \pm 0.2$ & $3.5 \pm 0.1$ & $3.8 \pm 0.4$ \\
\hline \multicolumn{5}{|c|}{ Globulin (g/dL) } \\
\hline M & $3.0 \pm 0.2$ & $2.9 \pm 0.2$ & $3.1 \pm 0.3$ & $2.9 \pm 0.3$ \\
\hline $\mathrm{F}$ & $2.7 \pm 0.1$ & $2.8 \pm 0.2$ & $2.9 \pm 0.2$ & $2.8 \pm 0.3$ \\
\hline \multicolumn{5}{|c|}{ T-Bili (mg/dL) } \\
\hline M & $0.11 \pm 0.10$ & $0.15 \pm 0.14$ & $0.25 \pm 0.24$ & $0.05 \pm 0.05$ \\
\hline $\mathrm{F}$ & $0.16 \pm 0.10$ & $0.17 \pm 0.20$ & $0.17 \pm 0.18$ & $0.12 \pm 0.06$ \\
\hline \multicolumn{5}{|c|}{ Glucose (mg/dL) } \\
\hline $\mathrm{M}$ & $127.7 \pm 14.8$ & $118.4 \pm 14.1$ & $112.2 \pm 14.1$ & $105.2 \pm 17.8$ \\
\hline $\mathrm{F}$ & $100.2 \pm 12.8$ & $101.3 \pm 13.7$ & $92.2 \pm 17.4$ & $105.2 \pm 14.9$ \\
\hline \multicolumn{5}{|c|}{ BUN (mg/dL) } \\
\hline M & $15.0 \pm 1.6$ & $13.4 \pm 1.8$ & $14.0 \pm 1.3$ & $14.1 \pm 2.2$ \\
\hline $\mathrm{F}$ & $16.7 \pm 3.7$ & $15.4 \pm 2.6$ & $15.9 \pm 1.3$ & $18.3 \pm 4.4$ \\
\hline \multicolumn{5}{|c|}{ Crea (mg/dL) } \\
\hline M & $0.5 \pm 0.1$ & $0.5 \pm 0.0$ & $0.6 \pm 0.1$ & $0.6 \pm 0.1$ \\
\hline $\mathrm{F}$ & $0.6 \pm 0.0$ & $0.5 \pm 0.1$ & $0.6 \pm 0.1$ & $0.6 \pm 0.1$ \\
\hline \multicolumn{5}{|c|}{$\mathrm{Na}(\mathrm{mEq} / \mathrm{dL})$} \\
\hline $\mathrm{M}$ & $143.5 \pm 0.8$ & $144.1 \pm 0.9$ & $143.0 \pm 0.9$ & $145.4 \pm 1.5^{* *}$ \\
\hline $\mathrm{F}$ & $144.3 \pm 1.1$ & $143.7 \pm 0.8$ & $143.7 \pm 0.9$ & $144.9 \pm 1.4$ \\
\hline \multicolumn{5}{|l|}{$\mathrm{K}(\mathrm{mEq} / \mathrm{dL})$} \\
\hline $\mathrm{M}$ & $3.6 \pm 0.3$ & $3.5 \pm 0.2$ & $3.7 \pm 0.4$ & $3.6 \pm 0.3$ \\
\hline F & $3.8 \pm 0.3$ & $3.8 \pm 0.3$ & $3.8 \pm 0.2$ & $4.0 \pm 0.3$ \\
\hline \multicolumn{5}{|l|}{$\mathrm{Cl}(\mathrm{mEq} / \mathrm{dL})$} \\
\hline$M$ & $102.4 \pm 1.5$ & $102.3 \pm 0.7$ & $103.1 \pm 1.2$ & $101.5 \pm 2.2$ \\
\hline $\mathrm{F}$ & $102.7 \pm 1.4$ & $103.5 \pm 1.4$ & $103.8 \pm 1.1$ & $104.3 \pm 0.9^{*}$ \\
\hline \multicolumn{5}{|l|}{$\mathrm{Ca}(\mathrm{mg} / \mathrm{dL})$} \\
\hline M & $10.9 \pm 0.2$ & $10.8 \pm 0.1$ & $10.9 \pm 0.2$ & $11.0 \pm 0.4$ \\
\hline F & $10.1 \pm 0.3$ & $10.0 \pm 0.2$ & $9.9 \pm 0.2$ & $10.0 \pm 0.2$ \\
\hline \multicolumn{5}{|l|}{$\mathrm{P}(\mathrm{mg} / \mathrm{dL})$} \\
\hline M & $4.8 \pm 0.7$ & $5.0 \pm 1.1$ & $4.5 \pm 0.5$ & $4.8 \pm 1.6$ \\
\hline $\mathrm{F}$ & $6.5 \pm 0.8$ & $6.2 \pm 0.5$ & $6.5 \pm 0.7$ & $6.0 \pm 0.6$ \\
\hline
\end{tabular}

All values are means $\pm \mathrm{SD}(n=10) .{ }^{*} P<0.05,{ }^{* *} P<0.01$ compared with control group. M: male; F: female. T-Bili: total bilirubin; and Crea: creatinine. 
TABLE 4: Absolute organ weight of SD male and female rats fed with 800, 1600, and $2400 \mathrm{mg} / \mathrm{kg}$ DTTE for 90 days.

\begin{tabular}{|c|c|c|c|c|}
\hline Item & Control & $800 \mathrm{mg}$ & $1600 \mathrm{mg}$ & $2400 \mathrm{mg}$ \\
\hline \multicolumn{5}{|c|}{$\begin{array}{l}\text { Brain (g) } \\
\text { (g/100 g b.w.) }\end{array}$} \\
\hline M & $\begin{array}{c}2.19 \pm 0.11 \\
(0.42 \pm 0.04)\end{array}$ & $\begin{array}{c}2.21 \pm 0.09 \\
(0.42 \pm 0.03)\end{array}$ & $\begin{array}{c}2.14 \pm 0.05 \\
(0.40 \pm 0.03)\end{array}$ & $\begin{array}{c}2.16 \pm 0.08 \\
(0.42 \pm 0.04)\end{array}$ \\
\hline $\mathrm{F}$ & $\begin{array}{c}2.03 \pm 0.02 \\
(0.73 \pm 0.04)\end{array}$ & $\begin{array}{c}1.99 \pm 0.02 \\
(0.71 \pm 0.06)\end{array}$ & $\begin{array}{c}2.07 \pm 0.01 \\
(0.74 \pm 0.05)\end{array}$ & $\begin{array}{c}2.01 \pm 0.02 \\
(0.72 \pm 0.04)\end{array}$ \\
\hline \multicolumn{5}{|c|}{$\begin{array}{l}\text { Pituitary (mg) } \\
\text { (mg/100 g b.w.) }\end{array}$} \\
\hline $\mathrm{M}$ & $\begin{array}{l}13.3 \pm 6.8 \\
(2.5 \pm 1.4)\end{array}$ & $\begin{array}{c}10.3 \pm 1.5 \\
(2.0 \pm 0.4)\end{array}$ & $\begin{array}{c}10.6 \pm 1.5 \\
(2.0 \pm 0.4)\end{array}$ & $\begin{array}{c}12.4 \pm 5.1 \\
(2.4 \pm 0.9)\end{array}$ \\
\hline $\mathrm{F}$ & $\begin{array}{c}15.8 \pm 2.3 \\
(5.5 \pm 0.8)\end{array}$ & $\begin{array}{c}17.4 \pm 6.6 \\
(6.2 \pm 2.4)\end{array}$ & $\begin{array}{l}14.6 \pm 2.8 \\
(5.3 \pm 1.3)\end{array}$ & $\begin{array}{l}13.2 \pm 3.0 \\
(4.7 \pm 1.1)\end{array}$ \\
\hline \multicolumn{5}{|c|}{$\begin{array}{l}\text { Heart (g) } \\
\text { (g/100 g b.w.) }\end{array}$} \\
\hline $\mathrm{M}$ & $\begin{array}{c}1.52 \pm 0.13 \\
(0.29 \pm 0.03)\end{array}$ & $\begin{array}{c}1.52 \pm 0.13 \\
(0.29 \pm 0.03)\end{array}$ & $\begin{array}{c}1.49 \pm 0.11 \\
(0.28 \pm 0.02)\end{array}$ & $\begin{array}{c}1.52 \pm 0.13 \\
(0.29 \pm 0.03)\end{array}$ \\
\hline $\mathrm{F}$ & $\begin{array}{c}0.93 \pm 0.10 \\
(0.33 \pm 0.03)\end{array}$ & $\begin{array}{c}0.94 \pm 0.09 \\
(0.34 \pm 0.04)\end{array}$ & $\begin{array}{c}0.94 \pm 0.06 \\
(0.34 \pm 0.04)\end{array}$ & $\begin{array}{c}0.95 \pm 0.10 \\
(0.34 \pm 0.03)\end{array}$ \\
\hline \multicolumn{5}{|c|}{$\begin{array}{l}\text { Liver (g) } \\
\text { (g/100 g b.w.) }\end{array}$} \\
\hline M & $\begin{array}{l}12.7 \pm 2.1 \\
(2.4 \pm 0.4)\end{array}$ & $\begin{array}{c}12.0 \pm 1.6 \\
(2.3 \pm 0.3)\end{array}$ & $\begin{array}{c}11.8 \pm 1.7 \\
(2.2 \pm 0.3)\end{array}$ & $\begin{array}{c}12.3 \pm 1.8 \\
(2.4 \pm 0.4)\end{array}$ \\
\hline $\mathrm{F}$ & $\begin{array}{c}6.8 \pm 0.5 \\
(2.4 \pm 0.2)\end{array}$ & $\begin{array}{c}6.7 \pm 0.6 \\
(2.4 \pm 0.3)\end{array}$ & $\begin{array}{c}6.7 \pm 0.5 \\
(2.4 \pm 0.3)\end{array}$ & $\begin{array}{c}7.0 \pm 0.7 \\
(2.5 \pm 0.2)\end{array}$ \\
\hline \multicolumn{5}{|c|}{$\begin{array}{l}\text { Spleen (g) } \\
\text { (g/100 g b.w.) }\end{array}$} \\
\hline $\mathrm{M}$ & $\begin{array}{c}0.82 \pm 0.09 \\
(0.16 \pm 0.02)\end{array}$ & $\begin{array}{c}0.79 \pm 0.09 \\
(0.15 \pm 0.02)\end{array}$ & $\begin{array}{c}0.80 \pm 0.09 \\
(0.15 \pm 0.02)\end{array}$ & $\begin{array}{c}0.80 \pm 0.06 \\
(0.16 \pm 0.01)\end{array}$ \\
\hline $\mathrm{F}$ & $\begin{array}{c}0.54 \pm 0.09 \\
(0.19 \pm 0.03)\end{array}$ & $\begin{array}{c}0.54 \pm 0.06 \\
(0.19 \pm 0.02)\end{array}$ & $\begin{array}{c}0.54 \pm 0.07 \\
(0.20 \pm 0.03)\end{array}$ & $\begin{array}{c}0.50 \pm 0.03 \\
(0.18 \pm 0.01)\end{array}$ \\
\hline \multicolumn{5}{|c|}{$\begin{array}{l}\text { L kidneys (g) } \\
\text { (g/100 g b.w.) }\end{array}$} \\
\hline M & $\begin{array}{c}1.63 \pm 0.12 \\
(0.31 \pm 0.03)\end{array}$ & $\begin{array}{c}1.52 \pm 0.13 \\
(0.29 \pm 0.03)\end{array}$ & $\begin{array}{c}1.51 \pm 0.11 \\
(0.28 \pm 0.02)\end{array}$ & $\begin{array}{c}1.55 \pm 0.12 \\
(0.32 \pm 0.09)\end{array}$ \\
\hline $\mathrm{F}$ & $\begin{array}{c}0.83 \pm 0.09 \\
(0.30 \pm 0.04)\end{array}$ & $\begin{array}{c}0.84 \pm 0.08 \\
(0.30 \pm 0.03)\end{array}$ & $\begin{array}{c}0.85 \pm 0.07 \\
(0.30 \pm 0.04)\end{array}$ & $\begin{array}{c}0.82 \pm 0.07 \\
(0.29 \pm 0.02)\end{array}$ \\
\hline \multicolumn{5}{|c|}{$\begin{array}{l}\text { R kidneys (g) } \\
\text { (g/100 g b.w.) }\end{array}$} \\
\hline M & $\begin{array}{c}1.66 \pm 0.11 \\
(0.31 \pm 0.03)\end{array}$ & $\begin{array}{c}1.54 \pm 0.12 \\
(0.29 \pm 0.02)\end{array}$ & $\begin{array}{c}1.54 \pm 0.10 \\
(0.29 \pm 0.02)\end{array}$ & $\begin{array}{c}1.53 \pm 0.13 \\
(0.27 \pm 0.06)\end{array}$ \\
\hline $\mathrm{F}$ & $\begin{array}{c}0.86 \pm 0.09 \\
(0.31 \pm 0.04)\end{array}$ & $\begin{array}{c}0.87 \pm 0.09 \\
(0.31 \pm 0.04)\end{array}$ & $\begin{array}{c}0.85 \pm 0.06 \\
(0.31 \pm 0.04)\end{array}$ & $\begin{array}{c}0.84 \pm 0.07 \\
(0.30 \pm 0.02)\end{array}$ \\
\hline \multicolumn{5}{|c|}{$\begin{array}{l}\text { L adrenal (mg) } \\
\text { (mg/100 g b.w.) }\end{array}$} \\
\hline $\mathrm{M}$ & $\begin{array}{l}25.0 \pm 1.4 \\
(4.8 \pm 1.0)\end{array}$ & $\begin{array}{l}29.6 \pm 1.5 \\
(5.6 \pm 1.0)\end{array}$ & $\begin{array}{c}29.7 \pm 1.7 \\
(5.6 \pm 0.8)\end{array}$ & $\begin{array}{c}27.3 \pm 1.4 \\
(5.3 \pm 1.0)\end{array}$ \\
\hline $\mathrm{F}$ & $\begin{array}{c}31.3 \pm 6.1 \\
(11.2 \pm 2.3)\end{array}$ & $\begin{array}{c}32.6 \pm 5.5 \\
(11.7 \pm 1.9)\end{array}$ & $\begin{array}{c}30.0 \pm 4.5 \\
(10.7 \pm 2.0)\end{array}$ & $\begin{array}{c}32.6 \pm 6.1 \\
(11.7 \pm 2.5)\end{array}$ \\
\hline
\end{tabular}


TABle 4: Continued.

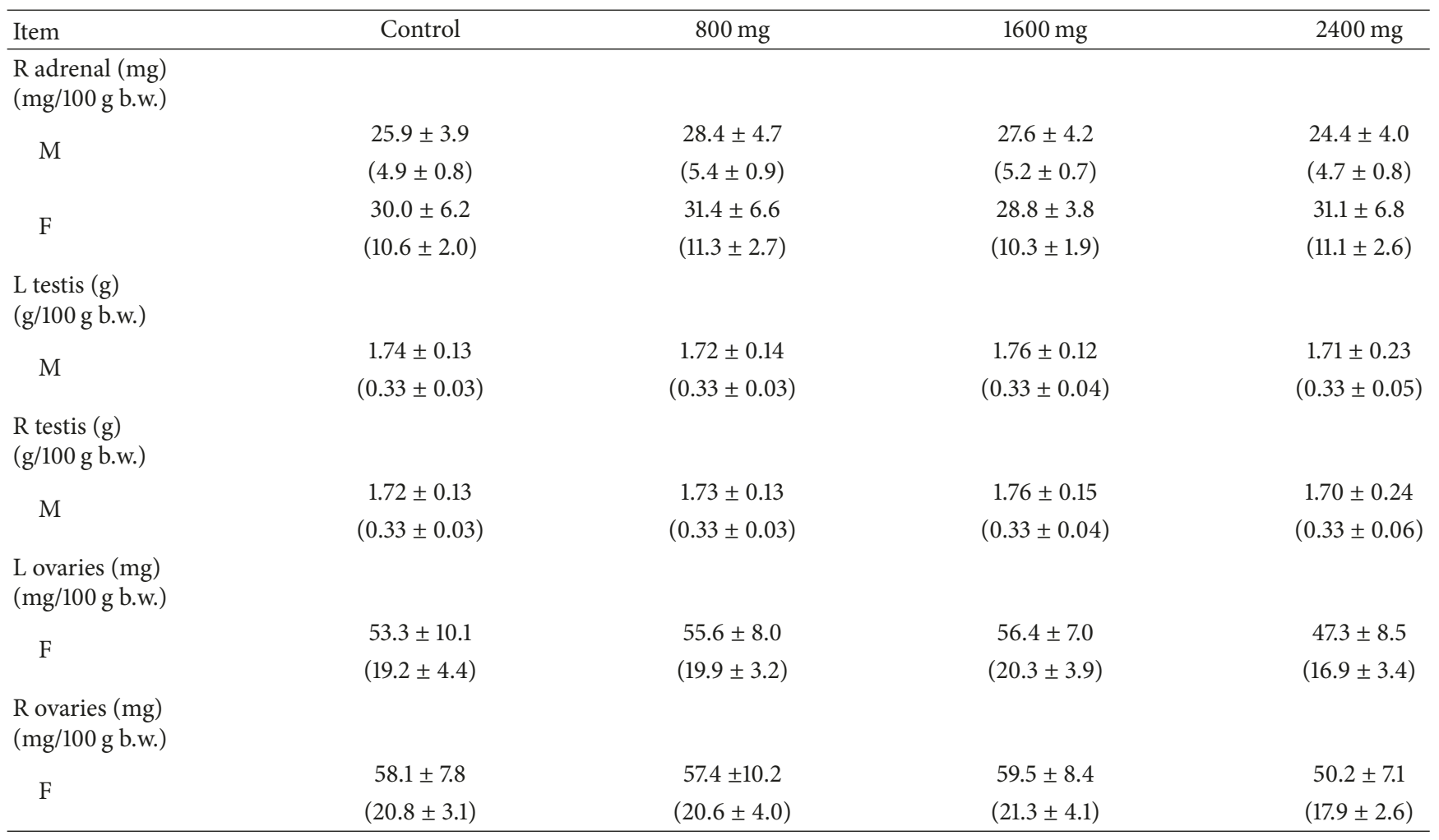

All values are means \pm SD $(n=10)$. ( ): relative weight; b.w.: body weight; M: male; F: female; L: left; and R: right.

in the stomach. Though some differences were observed, these results were not considered relevant to the test article treatment (Table 5).

\subsection{Genotoxicity Studies}

3.2.1. Bacterial Reverse Mutation Assay. Before the Ames test, all strains were treated with DTTE at $1.25,2.5$, or $5 \mathrm{mg} /$ plate for $18 \mathrm{~h}$ to evaluate the toxicity effects (Table 6 ). The results showed that DTTE had no significant toxic effect on the strains at any of the administered doses. In the Ames test, for which DTTE was directly applied to the strain at 0.3125 , $0.625,1.25,2.5$, or $5 \mathrm{mg} /$ plate for $48 \mathrm{~h}$ with and without S9 mix, the number of mutant bacteria was not more than 2fold higher than in the negative control group in both the presence and absence of S9 mixture (Table 7). Thus, DTTE did not induce mutations in the Salmonella reverse mutation assay.

3.2.2. In Vivo Mammalian Cell Micronucleus Test. Cyclophosphamide is a known mutagenic agent that affects RBC metabolism and causes double-strand breaks in DNA. Our results showed that the ratio of micronucleated (MN) RBCs to RETs was significantly increased in the cyclophosphamidetreated group compared with that in the control group after 24 and $48 \mathrm{~h}$ of treatment. Furthermore, the ratio of RETs to normochromatic erythrocytes (NCEs) in the cyclophosphamide-treated group was significantly decreased compared with that in the control group after 24 and $48 \mathrm{~h}$ of treatment (Table 8). As for DTTE-treated groups, there was no significant difference compared with the control group in the ratio of MN/RETs or RETs/NCEs. The micronucleus test showed that DTTE did not affect the number of peritoneal MN RBCs or the production of RETs in mice.

\section{Discussion}

We evaluated the safety of DTTE in a 90-day subchronic study of oral toxicity and two genotoxicity studies of mammalian and bacterial systems and found that DTTE did not cause any general organ or systemic toxicity in low- or highdose-treated rats. The results of the Salmonella reverse mutation assay and the micronucleus test in mice demonstrated that DTTE is not mutagenic or genotoxic.

During the 90-day subchronic toxicity, there were no mortalities and no changes in the ophthalmological status, clinical status, body weight, food consumption, or food efficiency that were attributable to DTTE administration. Some isolated significant changes were observed in certain hematological and biochemical parameters in the DTTEtreated groups. However, these changes did not occur in both sexes and were not dose-dependent. Although the platelet count in the males of the $2400-\mathrm{mg} / \mathrm{kg}$-DTTE-treated group was significantly different than that in the control group, the value was still within the normal range [14] Nevertheless, the ratio of lymphocytes to segmented neutrophils in $800 \mathrm{mg} / \mathrm{kg}$ DTTE-treated group in females significantly 
TABLE 5: Histopathological examination of SD male and female rats fed with 800, 1600, and $2400 \mathrm{mg} / \mathrm{kg}$ DTTE for 90 days.

\begin{tabular}{|c|c|c|c|c|c|}
\hline \multirow{3}{*}{ Organ } & \multirow{3}{*}{ Lesions } & \multicolumn{4}{|c|}{ Group } \\
\hline & & \multicolumn{2}{|r|}{ Male } & \multicolumn{2}{|r|}{ Female } \\
\hline & & $\mathrm{H}_{2} \mathrm{O}$ & DTTE $2.4 \mathrm{~g} / \mathrm{kg}$ & $\mathrm{H}_{2} \mathrm{O}$ & DTTE $2.4 \mathrm{~g} / \mathrm{kg}$ \\
\hline Adrenal & & - & - & - & - \\
\hline Aorta & & - & - & - & - \\
\hline Brain & & - & - & - & - \\
\hline Brain stem & & - & - & - & - \\
\hline Bone & & - & - & - & - \\
\hline Bone marrow & & - & - & - & - \\
\hline Esophagus & & - & - & - & - \\
\hline Eye & & - & - & - & - \\
\hline \multicolumn{6}{|l|}{ Heart } \\
\hline & Infiltration, mononuclear cell, focal, minimal to slight ${ }^{2}$ & $2 / 10^{1}$ & $1 / 10$ & - & - \\
\hline Intestine & & - & - & - & - \\
\hline \multicolumn{6}{|l|}{ Kidney } \\
\hline & Hydronephrosis, pelvis, focal, slight to moderate & $2 / 10$ & - & - & - \\
\hline & Infiltration, mononuclear cell, focal, slight & $1 / 10$ & - & - & - \\
\hline & Regeneration, tubule, focal, slight & $1 / 10$ & - & - & - \\
\hline Liver & & - & - & - & - \\
\hline Lung & & - & - & - & - \\
\hline Lymph node & & - & - & - & - \\
\hline Ovary & & $\mathrm{N}$ & $\mathrm{N}$ & - & - \\
\hline Oviduct & & $\mathrm{N}$ & $\mathrm{N}$ & - & - \\
\hline Pancreas & & - & - & - & - \\
\hline Parathyroid gland & & - & - & - & - \\
\hline \multicolumn{6}{|l|}{ Prostate } \\
\hline & Infiltration, mononuclear cell, focal, slight & $2 / 10$ & $2 / 10$ & $\mathrm{~N}$ & $\mathrm{~N}$ \\
\hline Sciatic nerve & & - & - & - & - \\
\hline Seminal vesicle & & - & - & - & - \\
\hline Skeletal muscle & & - & - & - & - \\
\hline Spinal cord & & - & - & - & - \\
\hline \multirow[t]{2}{*}{ Stomach } & & - & - & - & - \\
\hline & Epidermoid cyst, focal, moderate & - & - & - & $1 / 10$ \\
\hline Spleen & & - & - & - & - \\
\hline Testes & & - & - & $\mathrm{N}$ & $\mathrm{N}$ \\
\hline Thymus & & - & - & - & - \\
\hline Thyroid gland & & - & - & - & - \\
\hline Trachea & & - & - & - & - \\
\hline Urinary bladder & & - & - & - & - \\
\hline Uterus & & $\mathrm{N}$ & $\mathrm{N}$ & - & - \\
\hline Vagina & & $\mathrm{N}$ & $\mathrm{N}$ & - & - \\
\hline
\end{tabular}

differed from the control group, but the lymphocyte and segmented neutrophil counts in the control and low-dose groups were not different. Additionally, biochemistry tests showed that sodium concentration in the high-dose group in males and the chloride concentration in the high-dose group in females were higher than the respective values in the control group, but still within the normal range [14]. No significant changes were found through the urinalysis, and the histopathological examination showed only slight mononuclear cell infiltration in the heart and prostate in the control and treatment groups in males and an epidermoid cyst in the stomach of one female rat in the treatment group. No positive correlations between the degree and incidence of the changes between the treatment and control groups were noted, and the histopathological changes were nonspecific. 
TABLE 6: Bactericidal effect of DTTE in Salmonella TA98, TA100, TA102, TA1535, and TA1537 tester strains.

\begin{tabular}{|c|c|c|c|c|c|}
\hline \multirow{2}{*}{ Tester strains } & \multirow{2}{*}{ Bacterial concentration } & \multicolumn{4}{|c|}{ Conc. (mg/plate)/number of revertants (colony, CFU/plate) } \\
\hline & & 0 & 1.25 & 2.5 & 5 \\
\hline \multirow{2}{*}{ TA98 } & $10^{-6} / \mathrm{ml}$ & $192.0 \pm 11.0$ & $195.0 \pm 10.8$ & $196.7 \pm 4.6$ & $200.3 \pm 9.0$ \\
\hline & $10^{-7} / \mathrm{ml}$ & $24.0 \pm 2.2$ & $25.7 \pm 2.6$ & $23.7 \pm 3.3$ & $25.0 \pm 4.5$ \\
\hline \multirow{2}{*}{ TA100 } & $10^{-6} / \mathrm{ml}$ & $209.0 \pm 4.5$ & $204.0 \pm 5.4$ & $214.3 \pm 2.6$ & $208.0 \pm 7.8$ \\
\hline & $10^{-7} / \mathrm{ml}$ & $25.7 \pm 4.2$ & $26.3 \pm 3.9$ & $27.3 \pm 2.1$ & $25.3 \pm 2.6$ \\
\hline \multirow{2}{*}{ TA102 } & $10^{-6} / \mathrm{ml}$ & $213.0 \pm 6.7$ & $208.7 \pm 9.8$ & $224.0 \pm 7.8$ & $221.3 \pm 8.2$ \\
\hline & $10^{-7} / \mathrm{ml}$ & $24.0 \pm 2.4$ & $25.0 \pm 2.8$ & $27.7 \pm 3.4$ & $28.3 \pm 4.0$ \\
\hline \multirow{2}{*}{ TA1535 } & $10^{-6} / \mathrm{ml}$ & $123.3 \pm 4.1$ & $122.3 \pm 5.4$ & $122.0 \pm 9.1$ & $126.3 \pm 4.9$ \\
\hline & $10^{-7} / \mathrm{ml}$ & $12.3 \pm 2.1$ & $10.0 \pm 5.4$ & $10.7 \pm 0.5$ & $9.3 \pm 3.9$ \\
\hline \multirow{2}{*}{ TA1537 } & $10^{-6} / \mathrm{ml}$ & $21.0 \pm 3.3$ & $23.7 \pm 1.7$ & $22.7 \pm 3.3$ & $21.0 \pm 2.2$ \\
\hline & $10^{-7} / \mathrm{ml}$ & $6.0 \pm 0.8$ & $8.3 \pm 1.7$ & $7.7 \pm 0.5$ & $5.7 \pm 1.7$ \\
\hline
\end{tabular}

Data are expressed as the mean $\pm \mathrm{SD}(n=3)$.

TABLE 7: Revertant changes of DTTE on Salmonella typhimurium strains mutagenicity test in the presence and absence of S9 mixture.

\begin{tabular}{|c|c|c|c|c|c|c|c|}
\hline \multirow{2}{*}{ Compound } & \multirow{2}{*}{ Conc. (mg/plate) } & \multirow{2}{*}{ S9 } & \multicolumn{5}{|c|}{ Number of revertants (colony/plate) } \\
\hline & & & TA98 & TA100 & TA102 & TA1535 & TA1537 \\
\hline \multirow[t]{3}{*}{ Negative control } & 0 & - & $31.7 \pm 3.9$ & $183.7 \pm 7.0$ & $268.7 \pm 20.4$ & $12.3 \pm 2.1$ & $11.0 \pm 4.3$ \\
\hline & 0.3125 & - & $26.0 \pm 1.6$ & $186.3 \pm 6.1$ & $268.0 \pm 15.6$ & $9.3 \pm 1.2$ & $12.3 \pm 2.5$ \\
\hline & 0.625 & - & $26.0 \pm 1.6$ & $185.3 \pm 6.9$ & $274.3 \pm 21.7$ & $10.0 \pm 2.9$ & $12.7 \pm 0.5$ \\
\hline \multirow[t]{3}{*}{ DTTE } & 1.25 & - & $24.0 \pm 2.2$ & $180.7 \pm 2.9$ & $275.3 \pm 10.3$ & $11.0 \pm 1.4$ & $10.0 \pm 2.9$ \\
\hline & 2.5 & - & $27.3 \pm 2.1$ & $181.3 \pm 11.0$ & $269.3 \pm 12.8$ & $10.0 \pm 0.8$ & $10.0 \pm 3.3$ \\
\hline & 5.0 & - & $25.3 \pm 1.7$ & $182.0 \pm 4.9$ & $279.0 \pm 26.5$ & $13.3 \pm 1.9$ & $14.3 \pm 2.1$ \\
\hline 4-NQO & & - & $172.3 \pm 32.3^{*}$ & & & & \\
\hline NaN3 & & - & & $2208.0 \pm 43.6^{*}$ & & $552.7 \pm 29.8^{*}$ & \\
\hline MMC & & - & & & $2113.3 \pm 357.4^{*}$ & & \\
\hline 9-AA & & - & & & & & $1499.3 \pm 68.7^{*}$ \\
\hline \multirow[t]{3}{*}{ Negative control } & & + & $24.7 \pm 3.1$ & $182.7 \pm 7.7$ & $309.7 \pm 22.4$ & $11.3 \pm 4.5$ & $9.0 \pm 2.2$ \\
\hline & 0.3125 & + & $31.0 \pm 1.6$ & $177.7 \pm 9.0$ & $310.7 \pm 28.5$ & $11.3 \pm 1.9$ & $12.7 \pm 3.1$ \\
\hline & 0.625 & + & $32.7 \pm 5.2$ & $184.3 \pm 6.1$ & $316.3 \pm 21.9$ & $9.0 \pm 2.2$ & $7.7 \pm 0.9$ \\
\hline \multirow[t]{3}{*}{ DTTE } & 1.25 & + & $27.0 \pm 2.4$ & $183.3 \pm 6.9$ & $307.7 \pm 33.5$ & $10.0 \pm 3.3$ & $12.3 \pm 3.3$ \\
\hline & 2.5 & + & $27.3 \pm 2.1$ & $185.0 \pm 7.8$ & $330.3 \pm 29.8$ & $12.3 \pm 3.1$ & $8.7 \pm 1.9$ \\
\hline & 5.0 & + & $25.3 \pm 1.7$ & $186.7 \pm 2.6$ & $307.7 \pm 21.3$ & $14.7 \pm 2.4$ & $12.0 \pm 1.6$ \\
\hline 2-AA & & + & $2858.0 \pm 264.7^{*}$ & $3340.3 \pm 71.8^{*}$ & $1359.0 \pm 125.2^{*}$ & $230.0 \pm 6.7^{*}$ & $228.0 \pm 21.1^{*}$ \\
\hline
\end{tabular}

Data was presented as mean $\pm \mathrm{SD}(n=3$ replicate plates); negative control for Salmonella strains was added with sterile reversed osmosis water; positive reagents without S-9 mix reactions were $2.5 \mu \mathrm{g} /$ plate 4-nitroquinoline-N-oxide (4-NQO) for TA98, $5 \mu \mathrm{g} /$ plate sodium azide $\left(\mathrm{NaN}_{3}\right)$ for TA100, TA1535, and $0.5 \mu \mathrm{g} /$ plate mitomycin C (MMC) for TA102 and $50 \mu \mathrm{g} /$ plate 9-aminoacridine (9-AA) for TA1537; positive reagent with S-9 mix reactions was $5 \mu \mathrm{g} / \mathrm{plate} 2$ aminoanthracene (2-AA) for all tester strains. ${ }^{*}$ Significant difference of colonies more than twofold of negative control and treated groups at $P<0.05$.

Some previous studies have reported the toxicity evaluations of other D. species, such as D. officinale, D. candidum and D. moniliforme [15-17]. Lee et al. [15] investigated the acute toxicity of $D$. moniliforme aqueous extract by a single oral dose in Sprague-Dawley rats and found out that $D$. moniliforme aqueous extract did not induce any toxic effects in rats for both sexes. The genetic toxicity test and 90-day feeding test in rats of $D$. candidum are performed and results indicate that the aqueous extracts were without toxicity, genetic toxicity, and mutagenicity under the test dose [16]. In addition, the genetic test of $D$. officinale shows negative results [17]. Although previous toxicology studies of herba dendrobii show that some $D$. species are nontoxic, we though it is necessary to investigate a safety assessment of a new medicinal Dendrobium species, $D$. Taiseed Tosnobile. In this study, the outcomes of the present subchronic toxicity study showed that oral administration of DTTE at concentrations of up to $2400 \mathrm{mg} / \mathrm{kg}$ does not cause adverse effects in male or female rats and that DTTE does not cause any genotoxic effects. Thus, $D$. Taiseed Tosnobile, a new Dendrobium species, could be safe for possible use as an herb or herbal tea, provided that the margin of safety between the no-observed-adverse-effect level of $2400 \mathrm{mg} / \mathrm{kg}$ and estimated intake resulting from the proposed uses and use levels are adequate. 
TABLE 8: Mammalian cell micronucleus test of DTTE in mice treated with water, DTTE, or cyclophosphamide.

\begin{tabular}{|c|c|c|c|c|}
\hline Treatment & Dose $(\mathrm{mg} / \mathrm{kg})$ & Number of RET & $\%$ of $\mathrm{MN}$ in $\mathrm{RET}$ & RET/NCE (\%) \\
\hline \multicolumn{5}{|l|}{24 hours } \\
\hline Control & - & $1002.0 \pm 8.5$ & $2.0 \pm 0.7$ & $5.4 \pm 0.6$ \\
\hline \multirow{3}{*}{ DTTE } & 800 & $1006.0 \pm 8.7$ & $2.4 \pm 0.2$ & $5.9 \pm 0.9$ \\
\hline & 1600 & $1003.8 \pm 7.8$ & $2.2 \pm 0.6$ & $5.0 \pm 0.5$ \\
\hline & 2400 & $1005.3 \pm 3.1$ & $2.8 \pm 0.5$ & $5.6 \pm 0.9$ \\
\hline Cyclophosphamide & $100^{\mathrm{a}}$ & $987.7 \pm 29.7$ & $8.4 \pm 1.0^{* * *}$ & $2.1 \pm 0.3^{* * *}$ \\
\hline \multicolumn{5}{|l|}{48 hours } \\
\hline \multirow[t]{2}{*}{ Control } & & $997.8 \pm 8.8$ & $2.3 \pm 0.8$ & $5.4 \pm 1.1$ \\
\hline & 800 & $998.0 \pm 8.8$ & $1.9 \pm 0.9$ & $4.9 \pm 1.0$ \\
\hline \multirow[t]{2}{*}{ DTTE } & 1600 & $1000.7 \pm 3.9$ & $1.7 \pm 0.7$ & $4.7 \pm 1.2$ \\
\hline & 2400 & $995.3 \pm 7.0$ & $1.9 \pm 0.6$ & $5.2 \pm 0.7$ \\
\hline Cyclophosphamide & $100^{\mathrm{a}}$ & $1004.7 \pm 14.2$ & $12.9 \pm 2.3^{* * *}$ & $2.0 \pm 0.1^{* * *}$ \\
\hline
\end{tabular}

All values are means $\pm \mathrm{SD}(n=6) ;{ }^{* * *} P<0.001$ as compared with the control group; RET: reticulocytes; NCE: normochromatic erythrocyte; and MN: micronucleus. a: cyclophosphamide via intraperitoneal injection $(10 \mathrm{~mL} / \mathrm{kg})$.

\section{Conflicts of Interest}

The authors declare that they have no conflicts of interest.

\section{Acknowledgments}

This study was supported by grants from the Department of Health, Executive Yuan of the Republic of China (CCMP 100RD-108).

\section{References}

[1] C.-T. Wu, K.-S. Huang, C.-H. Yang et al., "Inhibitory effects of cultured Dendrobium tosaense on atopic dermatitis murine model," International Journal of Pharmaceutics, vol. 463, no. 2, pp. 193-200, 2014.

[2] Y. Li, C.-L. Wang, S.-X. Guo, J.-S. Yang, and P.-G. Xiao, "Two new compounds from Dendrobium candidum," Chemical \& Pharmaceutical Bulletin, vol. 56, no. 10, pp. 1477-1479, 2008.

[3] T. B. Ng, J. Liu, and J. H. Wong, "Review of research on Dendrobium, a prized folk medicine," Applied Microbiology and Biotechnology, vol. 93, no. 5, pp. 1795-1803, 2012.

[4] L.-C. Yang, C.-C. Hsieh, C.-L. Wen, C.-H. Chiu, and W.C. Lin, "Structural characterization of an immunostimulating polysaccharide from the stems of a new medicinal Dendrobium species: Dendrobium Taiseed Tosnobile," International Journal of Biological Macromolecules, vol. 103, pp. 1185-1193, 2017.

[5] Q. Li, J. Chen, Y. Li, T. Chen, J. Zou, and H. Wang, "Effect of polysaccharide of dendrobium candidum on proliferation and apoptosis of human corneal epithelial cells in high glucose," Medicine (United States), vol. 96, no. 32, 2017.

[6] C.-C. Tian, X.-Q. Zha, and J.-P. Luo, "A polysaccharide from Dendrobium huoshanense prevents hepatic inflammatory response caused by carbon tetrachloride," Biotechnology \& Biotechnological Equipment, vol. 29, no. 1, pp. 132-138, 2015.

[7] J.-H. Wang, J.-P. Luo, X.-Q. Zha, and B.-J. Feng, "Comparison of antitumor activities of different polysaccharide fractions from the stems of Dendrobium nobile Lindl," Carbohydrate Polymers, vol. 79, no. 1, pp. 114-118, 2010.

[8] Y. Zhao, Y. Son, S. Kim, Y. Jang, and J. Lee, "Antioxidant and anti-hyperglycemic activity of polysaccharide isolated from
Dendrobium chrysotoxum Lindl," Journal of Biochemistry and Molecular Biology, vol. 40, no. 5, pp. 670-677, 2007.

[9] L. C. Yang, T. J. Lu, C. C. Hsieh, and W. C. Lin, "Characterization and immunomodulatory activity of polysaccharides derived from Dendrobium tosaense," Carbohydrate Polymers, vol. 111, pp. 856-863, 2014.

[10] AOAC, Official Methods of Analysis, Association of Official Analytical Chemists, Washington, DC, USA, 16 edition, 1995.

[11] J. R. Latendresse, A. R. Warbrittion, H. Jonassen, and D. M. Creasy, "Fixation of testes and eyes using a modified Davidson's fluid: comparison with Bouin's fluid and conventional Davidson's fluid," Toxicologic Pathology, vol. 30, no. 4, pp. 524-533, 2002.

[12] USEPA, "In vitro Mammalian Chromosome Aberration Test. In: Health Effects Test Guidelines," in OPPTS Harmonized Test Guidelines, Series 870.5375, no. EPA 712-C-98-223, pp. 1-13, 1998.

[13] OECD, "In vitro mammalian chromosome aberration test. Guideline for the Testing of Chemicals, No. 473," OECD publications, 1997.

[14] M. L. A. Giknis and C. B. Clifford, Clinical laboratory parameters for Crl:CD(SD) rats, Charles River Laboratories, Wilmington, Mass, USA, 1999.

[15] M. Lee, H. Jung, M. Kim et al., "Acute toxicity and cytotoxicity evaluation of," Laboratory Animal Research, vol. 32, no. 3, pp. 144-150, 2016.

[16] X. Z. Feng, L. Chen, H. Zhou, Y. Tang, J. J. Chu, and Z. Y, "Research on toxicological security of dendrobium candidum protocorms," Chinese Journal of Health Laboratory Technology, no. 3, pp. 355-358, 2014.

[17] J. Y. X. Fu, Y. Xu, and C. J, “Toxicity and Safety Evaluation of Dendrobium officinale's extracting solution," Zhejiang Journal of Preventive Medicine, vol. 4, pp. 250-251, 1998. 


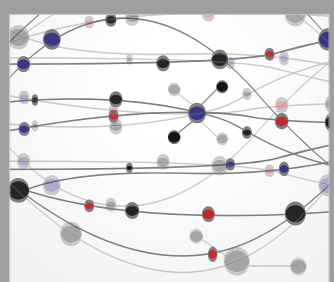

The Scientific World Journal
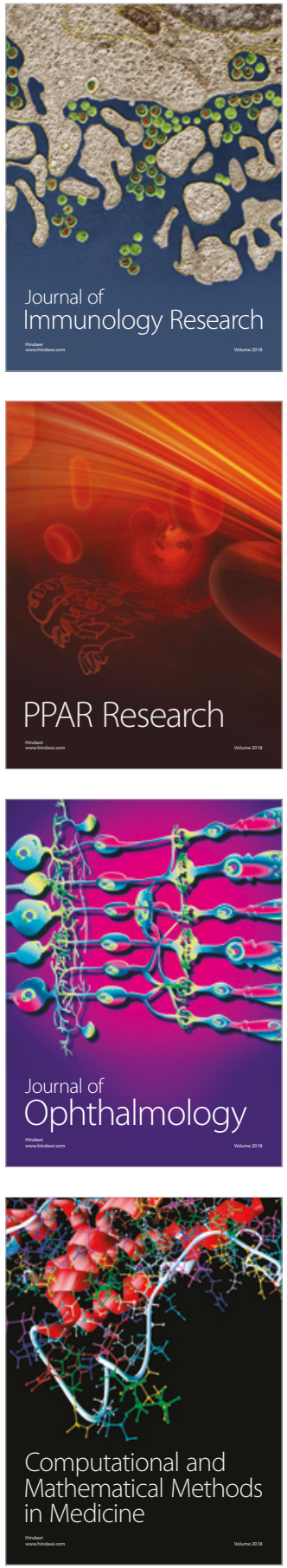

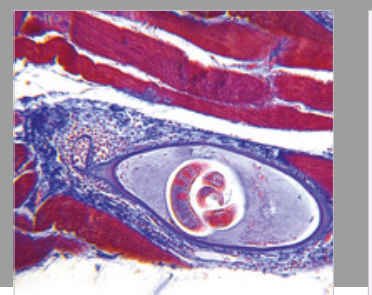

Gastroenterology Research and Practice

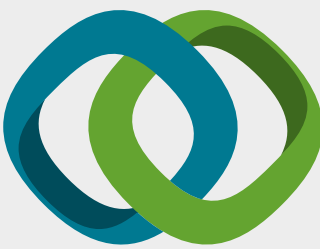

\section{Hindawi}

Submit your manuscripts at

www.hindawi.com
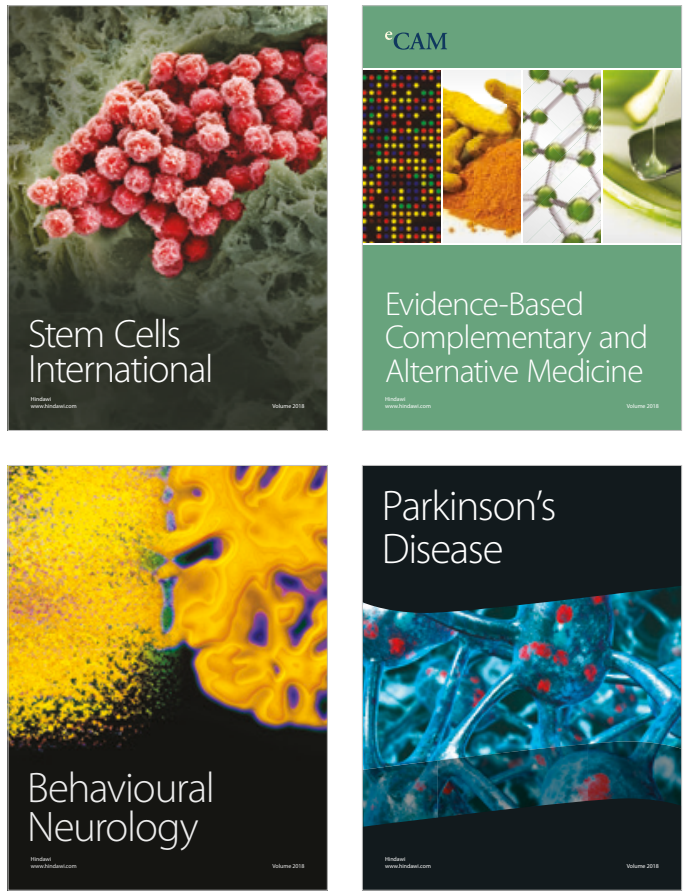

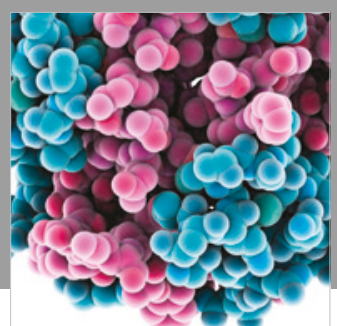

ournal of

Diabetes Research

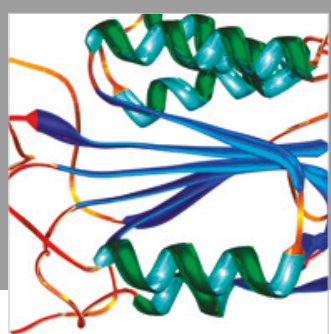

Disease Markers
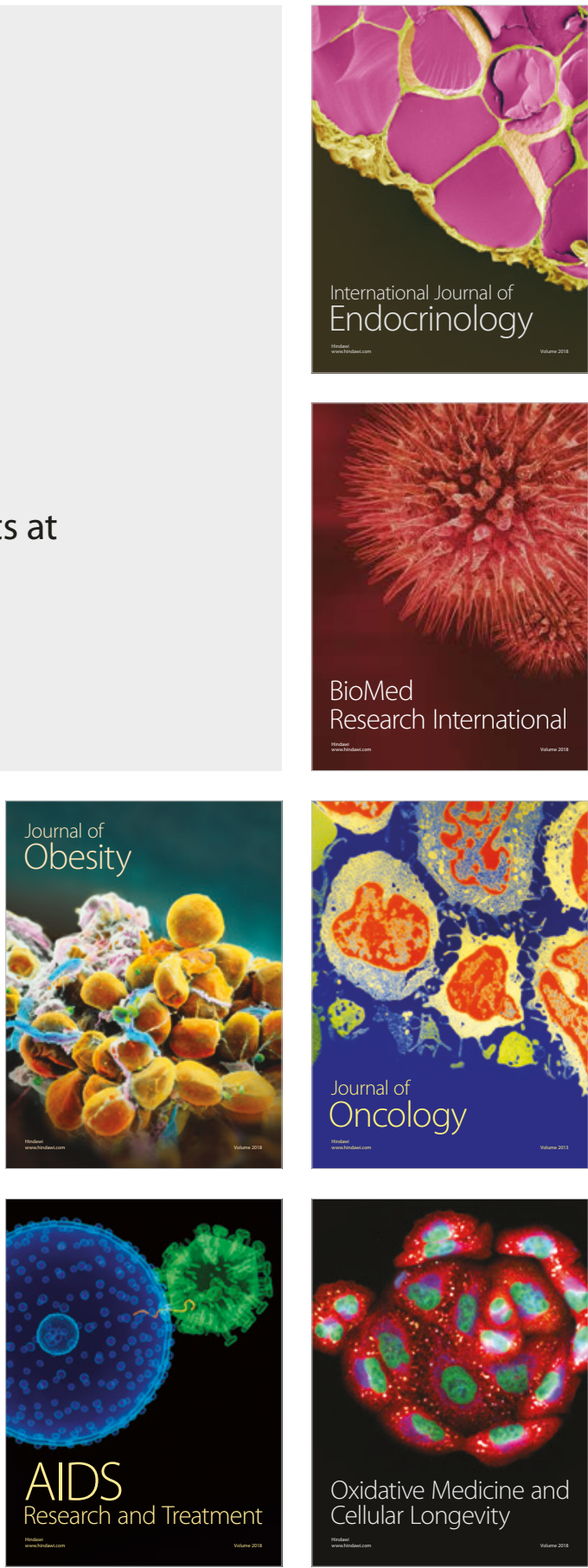